\title{
Investigating Potential Environmental Issues of using Recycled Materials in Road Construction
}

\author{
Vu Quoc Hung, Prasanna Egodawatta, Chaminda Gallage and Les Dawes
}

\begin{abstract}
Recycling of concrete and asphalt pavements has become the accepted approach to manage construction waste due to its economic and social benefits. Application of these products is mostly for road construction and low grade concrete due to the suitability of physical properties as an alternative product to replace the limited available quarry products. However, both the potential risk on human health and the environmental issues relating to use of recycled concrete aggregate (RCA) and reclaimed asphalt pavement (RAP) are a matter of concern. This paper provides a specific aspect of potential metals leaching in comparison with the ANZECC guidelines of water quality management. Also, this investigation comes up with a weak relationship between mineralogical compositions and leaching regime of metals, whereas availability of particle size distribution increases the ability of RCA and RAP to release metals.
\end{abstract}

Keywords - Recycled Concrete Aggregates (RCA), Reclaimed Asphalt Pavement (RAP), leaching, heavy metals, mineralogical composition.

\section{INTRODUCTION}

Re-use of construction wastes from demolished roadways and buildings is considered as an environmentally friendly solution. As classified by EU-Communities [1] (see Error! Reference source not found.). Among these seven, recycled concrete aggregates (RCA) and reclaimed asphalt pavements (RAP) are the most used in road construction and ground preparations [2]. The use of RCA and RAP has become common in the most parts of the world. In USA, approximately $70 \%$ production is used for road construction [3], while in Japan around $96 \%$ of recycled concrete was used as sub-base of structural roads [4]. In Australia, the rate of recycling concrete and asphalt in construction industry was $96 \%$ and

$\mathrm{Vu}$ Quoc Hung, Earth, Environmental and Biological Sciences, Queensland University of Technology, Australia, Email: quochung.vu@hdr.qut.edu.au

Prasanna Egodawatta, Earth, Environmental and Biological Sciences, Queensland University of Technology, Australia, Email: p.egodawatta@qut.edu.au

Chaminda Gallage, Civil Engineering and the Built Environment, Queensland University of Technology, Australia, Email: chaminda.gallage@qut.edu.au.

Les Dawes, Earth, Environmental and Biological Sciences, Queensland University of Technology, Australia, Email: l.dawes@qut.edu.au
99\% respectively [5].

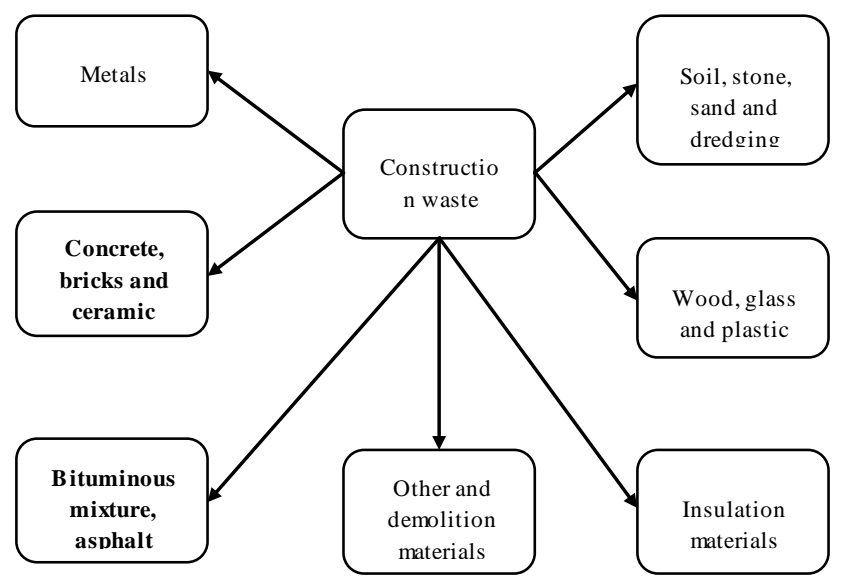

Fig.1 The classification of construction wastes [1]

There are many reasons for the increasing popularity of RCA and RAP in construction industry. Firstly, it is the limited availability of natural aggregates due to restrictions in mining and harvesting. Thus, the prices of natural aggregates such as crushed rocks are significantly high, imposing difficulties to use virgin aggregates[6]. Secondly, recycled construction materials are commonly regarded as a sustainable waste management practice [7]. This should be viewed in the context that most concrete and asphalt waste are generally disposed to landfills. Such practice can lead to land shortages and an increasing toll of solving environmental pollution from landfills [8]. Moreover, most prior studies indicated that many physical characteristic of RCA and RAP such as particle shape, density and water absorption, abrasion resistance, compressive strength and modulus of elasticity are suitable for a subgrade layer in road construction and could be an alternative materials to replace natural aggregate $[6,9,10]$.

Besides the benefits of using RCA and RAP, many challenges are also highlighted including insufficient awareness, lack of suitable technologies and lack of control and guidelines [4]. Among those challenges, the environmental issues relating to use of RCA and RAP, in particular leaching of chemical pollutants, have been identified as the most critical. As noted by Sakanakura, et al. [7], die-off of vegetation due to high-pH and high concentration of heavy metals associated to leachate from RCA are commonly reported. Furthermore, the release of organic compounds from RAP such as polycyclic 
aromatic hydrocarbons (PAHs) is also a potential consideration [11]. Leached pollutants from RCA and RAP may infiltrate through soil layers into groundwater and hence can increase the risk of health impacts via direct exposure or consumption in the form of drinking water [12].

The primary objective of the research study discussed in this paper is to identify potential heavy metals releasing from RCA and RAP and to determinate a maximum capacity of their leaching under extreme conditions. The research study outcomes are expected to develop a greater understanding of leaching regime in relation to characteristics of individual metals released and the availability of mineralogical compositions in RCA and RAP. The correlation between metals leached into water resources and their thresholds of water quality management was also evaluated as fundamental knowledge in order to provide general guidance for the use of RCA and RAP in practice.

\section{MATERIALS AND METHOD}

\section{A.The study site and samples collection}

Samples of RCA and RAP were collected from production plant (see Fig.2) provided by a local authority and a producer of recycled materials. Concrete waste and asphalt pavement were classified and crushed in accordance with a wide range of aggregate sizes before being moved to construction of new roads.

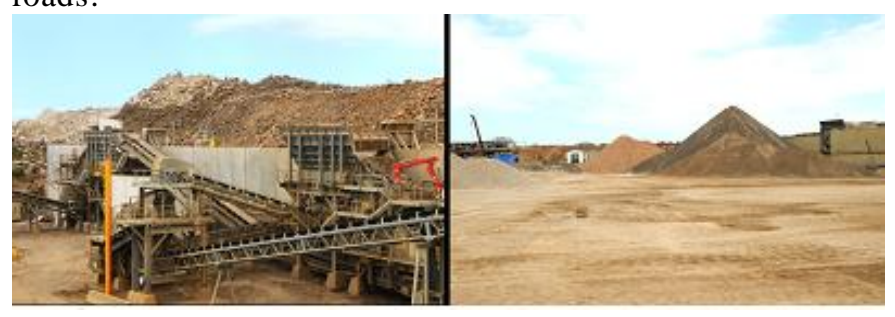

Fig. 2 Collection of samples at production plant

\section{B. Laboratory analysis}

The collected samples of RCA and RAP were divided into four portions to conduct the tests as listed in Table 1. Grain sizes distribution of RCA and RAP were carried out using dry sieve analysis in order to determine typical grain size. Mineralogy was identified by X-ray diffraction (XRD). The purpose of this test is to determine mineralogical phases in RCA and RAP. Potential leaching test was conducted to determine the maximum amount of heavy metals that can be leached under extreme conditions. Concentration of metals in leachate was determined by application of inductively coupled plasma mass spectrometry (ICP-MS).

Quality control (QC) and Quality assurance (QA) is a compulsory program to ensure accurate data in laboratory process. Accordingly, laboratory reagent blank (LRB), laboratory fortified blank (LFB), laboratory reagent blank (LRB) were used to evaluate laboratory performance. In addition, calibrations and internal standardization must be also used in the analytical method of metals. Recovery of LFB and LRB are required to drop within $85-115 \%$. Calibration standard used

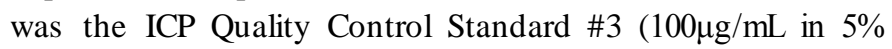
$\mathrm{HNO}_{3}$ ) provided by AccuStandard $囚$.

TABLE 1

PARAMETERS AND TEST METHODS

\begin{tabular}{|l|l|}
\hline Parameters & Test method \\
\hline Particle size distribution & $\begin{array}{l}\text { Particle size of soil test by sieving } \\
{[13]}\end{array}$ \\
\hline Mineralogy & X-ray diffraction [14] \\
\hline Potential leaching & $\begin{array}{l}\text { Leaching characteristic of building } \\
\text { material [15] }\end{array}$ \\
\hline Metals & ICP-MS, method 200.8 [16] \\
\hline
\end{tabular}

\section{RESULTS AND DISCUSSION}

\section{A. Particle size distribution}

The difference in grain size distribution clearly affects the leaching regime. The concentrations of substances leaching from recycled construction materials with finer aggregates are

larger than that with coarser aggregates [17-19]. Many standards of leaching tests such as AS-4439 [20], BS-EN-12457

[21] and ASTM-D4874-95 [22] indicated that 4mm is a threshold of particle size in leaching test. In this study, RCA and RAP were carried out to separate particle sizes using dry sieving and the results presented in

Fig.3. Particle size less than $4 \mathrm{~mm}$ for both RCA and RAP accounted for about $70 \%-80 \%$ of total grain sizes. Accordingly, the finer grains dominate particle size distribution of RCA and RAP and hence increasing ability of pollutants released.

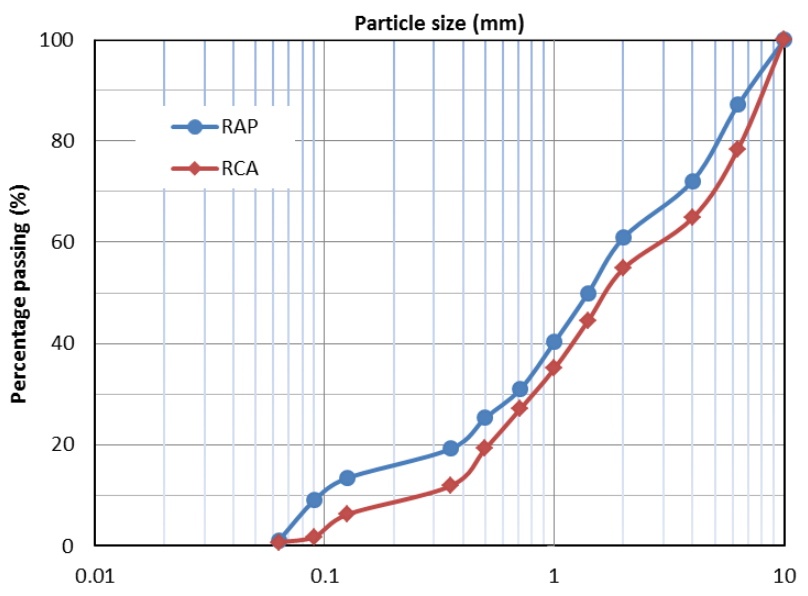

Fig.3 Particle size distribution of RCA and RAP 


\section{B. Mineralogy}

The proportions of crystalline minerals in RCA and RAP were determined by using X-ray diffraction technique as weight percentages of the mineralogical component. Mineralogical variations of RCA and RAP are presented in Table $2 \&$ Error! Reference source not found.4. The primary minerals of RCA contain Quartz, Muscovite, Calcite, Albite-Ca and Microcline, whereas the minor mineral components include Mica, Albite -Na, Kaolin, Tremolite and Chamosite. Similarly, Quartz is a major mineral in RAP. The proportions of other minerals in RAP, however, are significant difference in comparison with these of RCA. This could be the result of different sources of rock. Particularly, there is no Muscovite in any samples of RAP as illustrated in Table 2.

TABLE 2

MINERALOGICAL VARIATIONS IN RCA AND RAP

\begin{tabular}{|c|c|c|c|c|}
\hline No & Phase & Chemical form & $\begin{array}{l}\text { Weight } \\
\text { of RCA } \\
(\%)\end{array}$ & $\begin{array}{l}\text { Weigh } \\
\mathrm{t} \\
\text { of } \\
\text { RAP } \\
(\%)\end{array}$ \\
\hline 1 & Quartz & $\mathrm{SiO}_{2}$ & 52.7 & 49.4 \\
\hline 2 & Calcite & $\mathrm{CaCO}_{3}$ & 8 & 1.7 \\
\hline 3 & Muscovite & $\mathrm{KAl}_{2}\left(\mathrm{AlSi}_{3} \mathrm{O}_{10}\right)(\mathrm{FOH})_{2}$ & 16.7 & 0 \\
\hline 4 & Mica & $\mathrm{X}_{2} \mathrm{Y}_{4-6} \mathrm{Z}_{8} \mathrm{O}_{20}(\mathrm{OH}, \mathrm{F})_{4}$ & 2.3 & 12.1 \\
\hline 5 & Albite $-\mathrm{Na}$ & $\mathrm{NaAlSi}_{3} \mathrm{O}_{8}$ & 2.7 & 11.6 \\
\hline 6 & Albite-Ca & $\mathrm{Ca}\left(\mathrm{AlSi}_{3} \mathrm{O}_{8}\right)_{2}$ & 7.2 & 12.3 \\
\hline 7 & Microcline & $\mathrm{KAlSi}_{3} \mathrm{O}_{8}$ & 7 & 5.7 \\
\hline 8 & Kaolin & $\mathrm{Al}_{2} \mathrm{Si}_{2} \mathrm{O}_{5}(\mathrm{OH})_{4}$ & 1.1 & 1.3 \\
\hline 9 & Tremolite & $\mathrm{Ca}_{2} \mathrm{Mg}_{5} \mathrm{Si}_{8} \mathrm{O}_{22}(\mathrm{OH})_{2}$ & 1.6 & 2.2 \\
\hline 10 & Chamosite & $\begin{array}{l}\left(\mathrm{Fe}^{2+} / \mathrm{Mg}\right)_{5} \mathrm{Al}\left(\mathrm{AlSi}_{3} \mathrm{O}_{10}\right)(\mathrm{OH}) \\
8\end{array}$ & 0.7 & 3.7 \\
\hline
\end{tabular}

$\mathrm{X}$ is $\mathrm{K}, \mathrm{Na}$ or $\mathrm{Ca}$

$\mathrm{Y}$ is $\mathrm{Al}, \mathrm{Mg}$ or $\mathrm{Fe}$

$\mathrm{Z}$ is $\mathrm{Si}$ or $\mathrm{Al}$
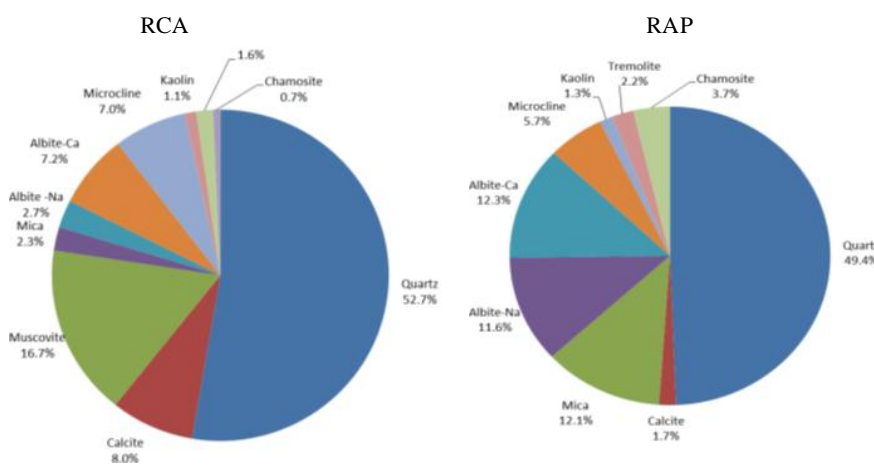

Fig.4 : Mineralogical composition of RCA and RAP

Quartz was the largest proportion in both RCA and RAP. This could be explained by a considerable amount of sand content that was derived from the establishment of original concrete and road surface [23]. Interestingly, Muscovite was only found in RCA due to such mineral is relation to the presence of brick and rock in construction waste. This could be an explanation for the absence of Muscovite in RAP.

\section{C.Potential leaching of metals}

Potential leaching test is to identify the maximum quantity of metals leaching from RCA and RAP under extreme conditions in the environment following the standard NEN-7341 [15]. Such conditions includes liquid to solid ratio $=100 \mathrm{~mL} / \mathrm{g}(\mathrm{L} / \mathrm{S}=100$ $\mathrm{mL} / \mathrm{g}), \mathrm{pH}=4$, grain size $<4 \mathrm{~mm}$ and contact time $=48 \mathrm{~h}$. The collected leachate was tested to determine the concentration of metals in accordance with the method 200.8 [16]. The analytical results were presented in Fig.5.

Fig.5 shows concentrations of metals released from RCA and RAP. There is a significant difference from such concentrations so dendogram pattern was used to classify those metals as illustrated in 6 \& Fig.7. This method is a tree diagram used to illustrate clusters classified by hierarchy. Accordingly, the metals in RCA and RAP were categorized into three groups. Group 1 including only $\mathrm{Ca}$ predominates in total of metals in leachate; while group 2 contained metals have concentrations above $1 \%$. The rest of metals accounted for less than $1 \%$ per an individual belonged to group 3 .

Distribution of mineralogical compositions presented a weak relationship to metals released. The leaching of $\mathrm{Ca}$ is a typical illustration of that. While Ca predominated in releasing regime of both RCA and RAP, minerals connected to the element such as Calcite and Albite-Ca was minor. It could be hypothesized that some elements in stable chemical form are difficult to be dissolved [24]. As pointed out by Gunawardana, et al. [25] metal elements were hardly adsorbed onto surfaces of crystalline minerals due to their ordered structure. As a result, such metal elements were easily dissolved in soil water. Hence, it could be argued that mineralogical compositions do not significantly affect leaching mechanis m of metals.

\section{Sources of metals and potentially environmental concerns}

The chemical composition of RCA and RAP inherits from original concrete and asphalt manufacturing process but also during operation. Consequently, potential pollutants leaching from RCA and RAP are related to chemical characteristics of used concrete and asphalt before recycling. In the case of RCA, metals and minerals can come from original cement, natural stones and concrete additives such as fly ash. Demolition, size reduction and storage may also result in the change of mineralogical phases leading to easier release under weather conditions [6]. In the case of RAP, metals could be absorbed into asphalt pavement from traffic activities. As noted by Nriagu [26], the principal source of $\mathrm{Pb}$ in RAP was provided by vehicle emissions because of using leaded gasoline Also, many metals including $\mathrm{Zn}, \mathrm{Mn}, \mathrm{Fe}, \mathrm{Co}, \mathrm{Ni}$ and $\mathrm{Cu}$ adhered to road surfaces as a result of tyre wear, brake wear 
and the corrosion of steel barriers [27] [28]. Additionally, heavy metals are available in additives and coarse aggregate of asphalt such as adhesive and crushed stones [29]. organs damage, although these metals are essential to assist the physical development [33]. Besides that, metals can be transported to agricultural soil leading to an increase concern due to the food safety issues and its negative impacts on soil

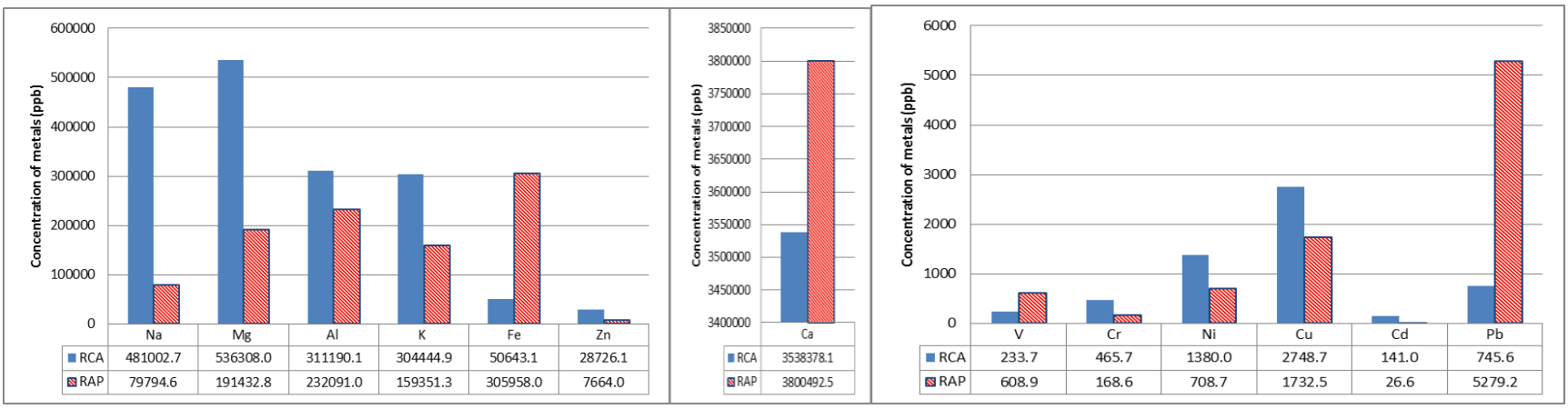

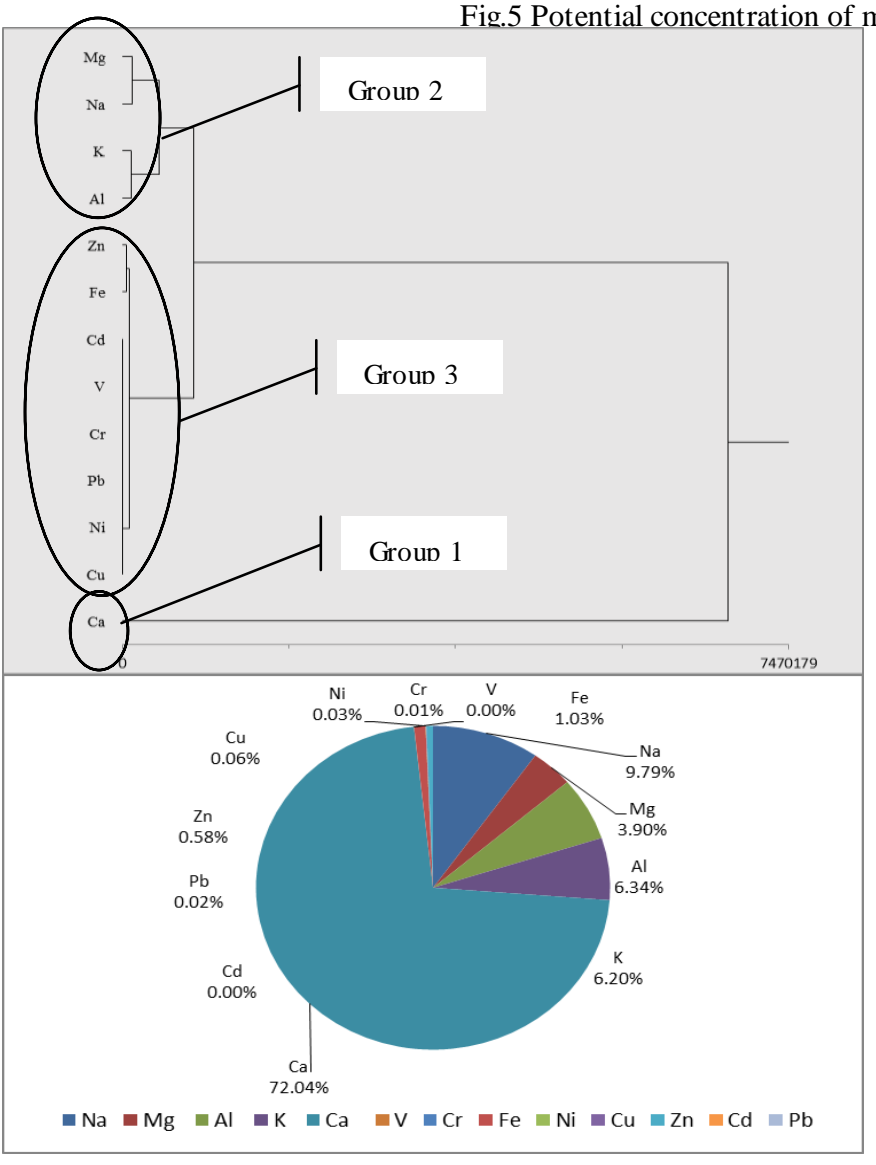

Fig. 6 Dendrogram and distribution of metals released from RCA in the potential leaching test

Many prior investigations indicated that such metals in excess of the acceptance thresholds in any water resource could risk human health. As noted by $\mathrm{Hu}$ [30], the absorption of $\mathrm{Pb}$ and $\mathrm{Cd}$ into human body due to exposure can result in hypertension and renal dysfunction respectively. Similarly, the ccumulation of $\mathrm{Al}$ in body is able to damage nervous system [31] , as well as the prolonged exposure to large amounts of $\mathrm{Ni}$ can cause allergies and skin diseases[32]. Likewise, an excessive intake of $\mathrm{Fe}, \mathrm{Cu}$ and $\mathrm{Zn}$ may lead to vomiting and ecosystems [34]. In this context, the Australian guideline ANZECC was used due to the sustainable management of water quality and human health risk [35]. Accordingly, the threshold concentrations of metals in water using for recreational purposes such as swimming and drinking were used. Any leaching liquid from solid waste into the environment were also tested following a guideline of the industrial waste management [36]. Results are illustrated in table 3.

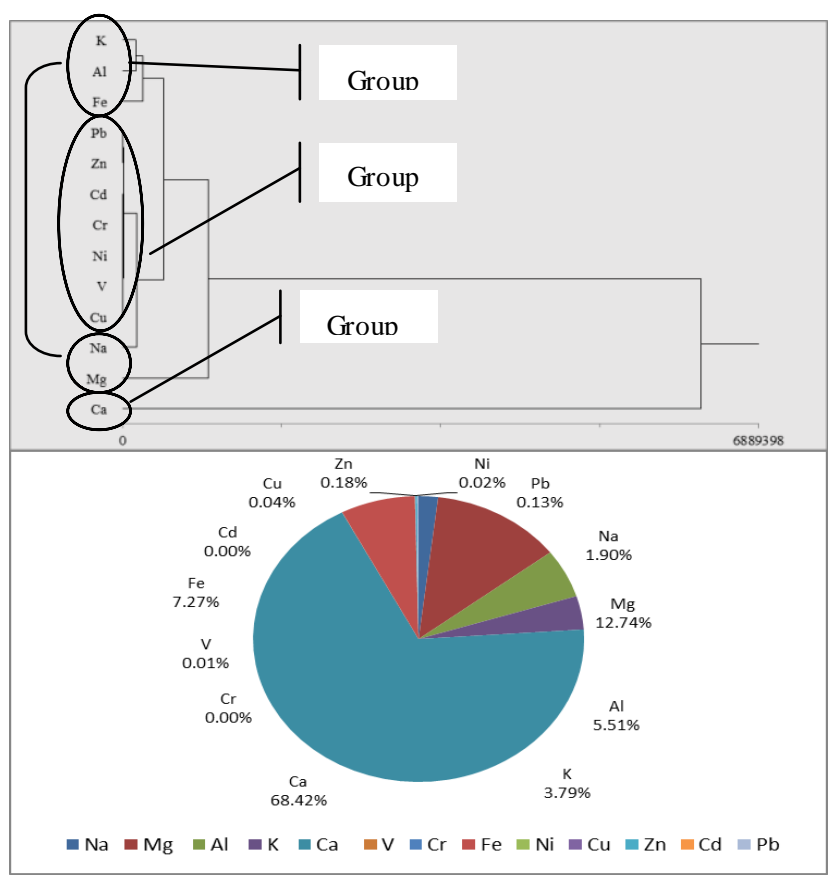

Fig.7 Dendrogram and distribution of metals released from RAP in the potential leaching test 
TABLE 3

COMPARISON BETWEEN CONCENTRATIONS OF METALS IN RCA \& RAP AND AUSTRALIAN STANDARD \& GUIDELINE

\begin{tabular}{|r|c|r|r|r|r|r|}
\hline $\begin{array}{r}\mathrm{N} \\
\mathrm{o}\end{array}$ & Metals & $\begin{array}{c}\mathrm{RCA} \\
(\mathrm{mg} / \mathrm{L})\end{array}$ & $\begin{array}{c}\text { RAP } \\
(\mathrm{mg} / \mathrm{L})\end{array}$ & $\begin{array}{c}\text { Recreation } \\
{[35]} \\
(\mathrm{mg} / \mathrm{L})\end{array}$ & $\begin{array}{c}\text { Drinking } \\
{[35]} \\
(\mathrm{mg} / \mathrm{L})\end{array}$ & $\begin{array}{c}\text { Industria } \\
\text { lwaste } \\
{[36]} \\
(\mathrm{mg} / \mathrm{L})\end{array}$ \\
\hline 1 & $\mathrm{Al}$ & 311.19 & 232.09 & 0.200 & $\mathrm{~N} / \mathrm{A}$ & N/A \\
\hline 2 & $\mathrm{Fe}$ & 50.64 & 305.96 & 0.300 & N/A & N/A \\
\hline 3 & $\mathrm{Zn}$ & 28.73 & 7.66 & 5.000 & N/A & 150.0 \\
\hline 4 & $\mathrm{Ni}$ & 1.38 & 0.71 & 0.100 & 0.020 & 1.0 \\
\hline 5 & $\mathrm{Cu}$ & 2.75 & 1.73 & 1.000 & 2.000 & 100.0 \\
\hline 6 & $\mathrm{Cd}$ & 0.14 & 0.03 & 0.005 & 0.002 & 0.1 \\
\hline 7 & $\mathrm{~Pb}$ & 0.75 & 5.28 & 0.050 & 0.010 & 0.5 \\
\hline
\end{tabular}

N/A: no reference value

Table 3 shows that all metals described in the standard \& guideline leaching from RCA and RAP considerably exceeds the thresholds in recreational use. Indeed, concentration of $\mathrm{Al}$ and $\mathrm{Fe}$ is larger (about 1500 times) than their acceptance thresholds in water quality used for recreation. Particularly, the amount of $\mathrm{Cd}$ in leachate of RCA is approximately 70 times higher than its threshold in drinking water and nearly 30 times the recreational limit. Similarly, the $\mathrm{Pb}$ released from RAP into the environment is greater than thresholds of drinking and recreational purposes (about 500 times and 100 times respectively), even though the presence of $\mathrm{Pb}$ in leachate of RAP is significantly higher (above 10 times) by comparis on with its maximum level in industrial waste. Hence, the leaching of metals from RCA and RAP become potentially issues concerning the environment and also risk to human health.

\section{CONCLUSION}

This report undertaken provide an in-depth understanding of potential metals leaching from RCA and RAP into the environment. Based on the data analysis, it can be concluded that the existing particle size distribution of RCA and RAP with above $70 \%$ of finer grains can increase ability of leaching metals. By contrast, presence of numerous crystalline minerals is mostly independent with releasing regime of metals due to not only stable chemical forms but also their ordered structure.

Results of potential leaching test indicated that almost heavy metals exceed their thresholds in ANZECC guideline of water quality management. Particularly, the excessive concentrations of $\mathrm{Cd}$ and $\mathrm{Pb}$ have been raising concerns about the environmental problems and risk human health.

\section{REFERENCES}

EU-Communities, "THE COMMISSION OF THE EUROPEAN COMMUNITIES, Having regard to the Treaty establishing the European Community, Having regard to Council Directive 75/442/EEC of 15 July 1975 on waste (1), as amended by Directive 91/156/EEC (2), and in particular Article 1 (a) thereof, Having regard to Council Directive 91/689/EEC of 12 December 1991 on hazardous waste (3), and in particular Article 1 (4), second indent thereof, Whereas," 2000.
C. S. Vieira and P. M. Pereira, "Use of recycled construction and demolition materials in geotechnical applications: A review," Resources, Conservation and Recycling, vol. 103, pp. 192-204, 10// 2015.

K. McNeil and T. K. Kang, "Recycled Concrete Aggregates: A Review," International Journal of Concrete Structures and Materials, vol. 7, pp. 61-69, 2013/03/01 2013.

A. Rao, K. N. Jha, and S. Misra, "Use of aggregates from recycled construction and demolition waste in concrete," Resources Conservation and Recycling, vol. 50, pp. 71-81, Mar 2007.

V. W. Y. Tam, "Comparing the implementation of concrete recycling in the Australian and Japanese construction industries," Journal of Cleaner Production, vol. 17, pp. 688702, 5// 2009.

J. Chen, J. Tinjum, and T. Edil, "Leaching of Alkaline Substances and Heavy Metals from Recycled Concrete Aggregate Used as Unbound Base Course," Transportation Research Record: Journal of the Transportation Research Board, vol. 2349, pp. 81-90, 12/01/ 2013.

H. Sakanakura, M. Osako, and A. Kida, "Effect of exposure test conditions on leaching behavior of inorganic contaminants from recycled materials for roadbeds," Waste Management, vol. 29, pp. 1658-1665, 5// 2009.

M. Safiuddin, U. J. Alengaram, M. M. Rahman, M. A. Salam, and M. Z. Jumaat, "Use of recycled concrete aggregate in concrete: a review," Journal of Civil Engineering and Management, vol. 19, pp. 796-810, 2013/12/01 2013.

A. Arulrajah, M. M. Disfani, S. Horpibulsuk, C. Suksiripattanapong, and N. Prongmanee, "Physical properties and shear strength responses of recycled construction and demolition materials in unbound pavement base/subbase applications," Construction and Building Materials, vol. 58, pp. 245-257, 5/15/ 2014.

A. Barbudo, F. Agrela, J. Ayuso, J. R. Jiménez, and C. S. Poon, "Statistical analysis of recycled aggregates derived from different sources for sub-base applications," Construction and Building Materials, vol. 28, pp. 129-138, 3// 2012.

M. Legret, L. Odie, D. Demare, and A. Jullien, "Leaching of heavy metals and polycyclic aromatic hydrocarbons from reclaimed asphalt pavement," Water Research, vol. 39, pp. 3675-3685, 9// 2005.

S. Butera, T. H. Christensen, and T. F. Astrup, "Composition and leaching of construction and demolition waste: Inorganic elements and organic compounds," Journal of Hazardous Materials, vol. 276, pp. 302-311, 7/15/ 2014.

ISO/DIS-17892, "Laboratory testing of soil-Determination of particle size distribution," ed, 2014.

G. W. Brindley and G. Brown, Crystal structures of clay minerals and their X-ray identification vol. 5: Oxford Univ Press, 1984.

NEN-7341, "Leaching characteristics of building material and solid waste material-leaching test- determination of leaching characteristics of inorganic components from granular and building materials," ed. The Netherlands: NNI Delft, 1992.

US.EPA, "Method 200.8 Trace elements in waters and wastes by inductively coupled plasma-mass spectrometry," in Revision 5.4, ed. Ohio: US Environmental Protection Agency, 1994.

R. W. Peters, "Chelant extraction of heavy metals from contaminated soils," Journal of Hazardous Materials, vol. 66, pp. 151-210, 4/23/ 1999.

T. Townsend, Y.-C. Jang, T. Tolaymat, and J. Jambeck, "Leaching tests for evaluating risk in solid waste management decision making," Final Report, pp. 03-01, 2003. 
[19] A. P. Galvín, J. Ayuso, I. García, J. R. Jiménez, and F. Gutiérrez, "The effect of compaction on the leaching and pollutant emission time of recycled aggregates from construction and demolition waste," Journal of Cleaner Production, vol. 83, pp. 294-304, 11/15/ 2014.

[20] AS-4439, "Waste, sediments and contaminated soils," ed, 1999.

[21] BS-EN-12457, "Characterisation of waste - leaching compliance test for leaching of granular waste materials and sludges," ed. European Committee for Standardisation, 2002.

[22] ASTM-D4874-95, "Standard test method for leaching solid material in a column apparatus," ed: American Society for Testing and Materials, 2006.

[23] M. C. Limbachiya, E. Marrocchino, and A. Koulouris, "Chemical-mineralogical characterisation of coarse recycled concrete aggregate," Waste Management, vol. 27, pp. 201208, // 2007

[24] D. S. Kosson, H. A. van der Sloot, and T. T. Eighmy, "An approach for estimation of contaminant release during utilization and disposal of municipal waste combustion residues," Journal of Hazardous Materials, vol. 47, pp. 43-75, 5// 1996.

[25] C. Gunawardana, P. Egodawatta, and A. Goonetilleke, "Role of particle size and composition in metal adsorption by solids deposited on urban road surfaces," Environmental pollution, vol. 184 , pp. 44-53, 2014.

[26] J. O. Nriagu, "The rise and fall of leaded gasoline," Science of the total environment, vol. 92, pp. 13-28, 1990.

[27] K. Adachi and Y. Tainosho, "Characterization of heavy metal particles embedded in tire dust," Environment international, vol. 30, pp. 1009-1017, 2004.

[28] L. Micbel and P. Christelle, "A preliminary assessment of the distribution of trace elements emitted by road traffic," Actes INRETS, pp. 63-69, 2003.

[29] S. W. Nanayakkara Mummullage, "Source characterisation of urban road surface pollutants for enhanced water quality predictions," PhD, 2015.

[30] H. Hu, "Human health and heavy metals," Life Support: The Environment and Human Health; MIT Press: Cambridge, MA, USA, p. 65, 2002.

[31] M. S. Arain, H. I. Afridi, T. G. Kazi, F. N. Talpur, M. B. Arain, A. Kazi, et al., "Correlation of aluminum and manganese concentration in scalp hair samples of patients having neurological disorders," Environmental monitoring and assessment, vol. 187, p. 1, 2015.

[32] M. van der Mark, R. Vermeulen, P. C. Nijssen, W. M. Mulleners, A. M. Sas, T. van Laar, et al., "Occupational exposure to solvents, metals and welding fumes and risk of Parkinson's disease," Parkinsonism \& related disorders, vol. 21, pp. 635-639, 2015.

[33] M. S. Toprak, H. L. Karlsson, and B. Fadeel, "Handbook on the Toxicology of Metals," 2014.

[34] L. Yu, Y.-b. Wang, G. Xin, Y.-b. SU, and W. Gang, "Risk assessment of heavy metals in soils and vegetables around non-ferrous metals mining and smelting sites, Baiyin, China," Journal of Environmental Sciences, vol. 18, pp. 1124-1134, 2006.

[35] A. Anzecc, "Australian and New Zealand guidelines for fresh and marine water quality," Australian and New Zealand Environment and Conservation Council and Agriculture and Resource Management Council of Australia and New Zealand, Canberra, pp. 1-103, 2000.

[36] E. Victoria, "Solid Industrial Waste Hazard Categorisation and Management, Industrial Waste Resource Guidelines,"
Environmental Protection Agency of Victoria, Melbourne, Australia. Publication No. IWRG, vol. 631, 2009. 